\title{
Sustainable Development for Teachers' Questioning Techniques for High Order Thinking Skill (HOTS)
}

Arshad bin Jais, Noraffandy bin Yahaya, Nor Hasniza binti Ibrahim

To Link this Article: http://dx.doi.org/10.6007/IJARBSS/v11-i1/8163

DOI:10.6007/IJARBSS/v11-i1/8163

Received: 06 November 2020, Revised: 30 November 2020, Accepted: 20 December 2020

Published Online: 12 January 2021

In-Text Citation: (Jais et al., 2021)

To Cite this Article: Jais, A. bin, Yahaya, N. bin, \& Ibrahim, N. H. binti. (2021). Sustainable Development for Teachers' Questioning Techniques for High Order Thinking Skill (HOTS). International Journal of Academic Research in Business and Social Sciences, 11(1), 114-125.

\section{Copyright: (c) 2021 The Author(s)}

Published by Human Resource Management Academic Research Society (www.hrmars.com)

This article is published under the Creative Commons Attribution (CC BY 4.0) license. Anyone may reproduce, distribute, translate and create derivative works of this article (for both commercial and non-commercial purposes), subject to full attribution to the original publication and authors. The full terms of this license may be seen at: http://creativecommons.org/licences/by/4.0/legalcode

Vol. 11, No. 1, 2021, Pg. 114 - 125

Full Terms \& Conditions of access and use can be found at http://hrmars.com/index.php/pages/detail/publication-ethics 


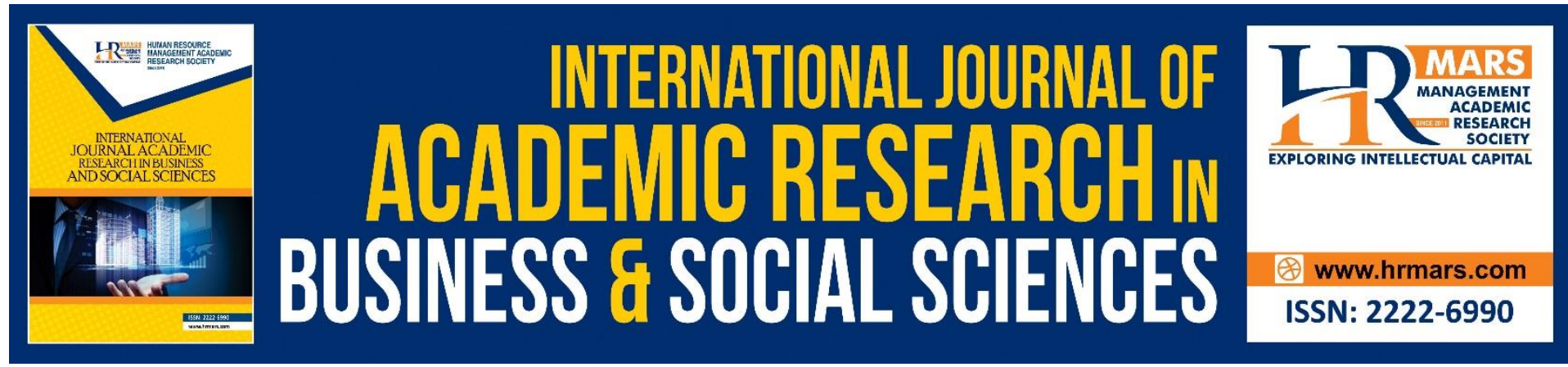

\title{
Sustainable Development for Teachers' Questioning Techniques for High Order Thinking Skill (HOTS)
}

\author{
Arshad bin Jais \\ State Department of Education, Sarawak \\ Email: arshadjais@ymail.com
}

\author{
Noraffandy bin Yahaya PhD, Nor Hasniza binti Ibrahim PhD \\ University of Technology Malaysia \\ Email: fandymcl@gmail.com, p-norhaniza@utm.my
}

\begin{abstract}
High Order thinking Skills (HOTS) is about the ability to apply knowledge, skills and values in reasoning, reflection, problem solving, decision making, innovating and creating something new. It is one of the components of the creative thinking skills and critical thinking, which enables someone to compare, evaluate, justify and make inference. Effective questioning sessions in classroom require advance preparation and questioning should be used to achieve well-defined goals. High-level questioning facilitates learning and stimulates students' active participation, besides improving their critical thinking skills. Routine applications of previously acquired knowledge cannot answer a question or solve a problem. Instead, this can be done once an expanded use of mind occurs which a person must interpret, analyse or manipulate information. This is because, higher order thinking is characterised as non-algorithmic, selfregulative, complex, effortful, meaningful, and providing multiple solutions, nuanced judgments, multiple criteria and uncertainty. This study aimed to establish the relationships between HOTS and Teachers' Questioning Techniques in Chemistry Subject in District Kuching, Sarawak. A total of 218 respondents were selected as respondents for this study. They comprised 12 chemistry teachers, 6 assistant senior administrators and 200 students. The sample size was determined using multistage random sampling technique. Five techniques used in chemistry teacher questioning were investigated. The study applied a correlation comparative research design. Questionnaire was used as data collection instruments. Data was analysed using frequencies, percentages, standard deviations; weighted means and Multiple Regression Analysis. The quantitative data was analysed using Statistical Package for Social Sciences Version 21 software as a tool of analysis. Thinking skills are deemed the most fundamental skills which can be developed in the classroom and are the key to high achievement for all students. Questioning skills are essential to good teaching. Teachers often use questions to ensure that students are attentive and engaged, and to assess students' understanding. Students are expected to be encouraged to express their
\end{abstract}


opinions, make decisions, to find a solution to a problem, or to generate new ideas on matters pertaining to the content of education with the use of more challenging high-level questions. Keywords: Sustainable Development, Teachers' Questioning, High Order Thinking Skills And Questioning Techniques.

\section{Introduction}

Sustainable development is a process which fulfils the needs of the current without compromising the ability of future generations to fulfil their own needs. Thus, sustainability is a paradigm for thinking about our future, in which societal, economic and environmental considerations are balanced in pursuing a better quality of life and development (Azeitero et al., 2015). Sustainable education has been considered as renewable resources to be geared towards the acquisition of key competences of 21st century including sustainable lifestyles, work and habitat (Van den Branden, 2015). Special sustainability competencies, as agreed by experts, are a requirement required for anyone to critically reflect on their epistemologies and ontologies, besides taking action as appropriate (Barth \& Michelsen, 2013). Sustainability competencies, better known as 21st Century competencies, include such aspects as systems thinking, the ability to anticipate future events, wise decision-taking, and a strategic and interpersonal competency, among others (Glasser, 2014).

Thinking involves is combining and arranging information and data mentally, done in a correct and meaningful sequence to understand problems or to solve them, whether related to new concepts and knowledge, making decision in believing and acting or coming up with ethical, effective and sustainable solutions for real-world problems. In the 21st century, thinking skills, particularly creativity is a vital ingredient for economic prosperity, rendering human creativity to be a major economic resource. The generation of knowledge through innovation and creativity is what the industries of the 21st century will increasingly rely on (Barbour, 2016). The importance for students to be equipped with decision making and, critical and creative thinking skills prior to entering the working world has often been emphasised by employers. Besides, the increase in labour productivity is also dependent on the quality of each individual's talent, namely creativity. Creativity and innovation are two important keys to attain success in all fields in this era of rapid development. In fact, creative ideas are highly needed for important business management activities, for example, processes to increase productivity, motivate employees, solve problems, make decisions and rapid technological change. Generating ideas is thus a crucial step in resolving a problem. A Higher order thinking skills (HOTS) activities that require high level creative thinking and action. HOTS is one of the components of the creative thinking skills and critical thinking. Knowing how to use both of these skills indicate one's ability to apply HOTS. Although everyone is capable to think, only few are capable to solve problems, find understanding and gain new insights in learning. Routine applications of previously acquired knowledge cannot A question to be answered or a problem to be solved cannot be done through routine applications of previously acquired knowledge. Instead, this can be done once an expanded use of mind occurs, which a person must interpret, analyse or manipulate information. This is because, higher order thinking is characterized characterised as non-algorithmic, selfregulative, complex, self-regulative effortful, meaningful, effortful and providing multiple solutions, nuanced judgments, multiple criteria and uncertainty. HOTS is a critical aspect in green skill development.

Questions are often used by teachers to ensure that their students are engaged and attentive, besides assessing their understanding (Albergaria, 2010a). Therefore, what 
matters is not only the intent of the question, but also the question itself. Its benefits to students include motivating students and ensuring their active participation, leading them to think and develop their own problem solving skills; improving academic achievement as well as developing metacognitive thinking; storing knowledge; and enabling students to form critical thinking skills. Questioning skills are essential to good teaching. The outcome of this method can be seen in terms of fantastic discussions among the students, even including those not directly involved, as they side with one of the views. The preparation and homework habits among students are positively affected by teachers who ensure their own effectiveness and that of their classes. High-level questioning facilitates learning and stimulates students' active participation, besides improving their critical thinking skills (Albergaria, 2010b). It enables the teachers to do more accurate evaluations to gauge whether their understudies are truly attentive and whether they understand well the material provided to them. Meanwhile, the use of open-ended questions is expected to result in active, collaborative learning to take place.

\section{Background of the Study}

Both critical thinking and creative thinking skills are teachable and learnable components of HOTS. However, according to some scholars, HOTS is also about thinking logically, reflectively, critically, creatively and metacognitively. Similarly, Facione (2006) stated that, reflective, logical and metacognitive thinking are also the sub skills of critical thinking. Hence, a conclusion can be made that HOTS is critical and creative thinking. One of the agreed definitions is that, critical thinking is an attitude of being disposed to consider in a thoughtful, perceptive manner the problems and subjects which come within the range of an individual's experience. Once new input of information is uploaded into the mind, received through the senses, the mind processes it by correlating it with existing information in memory. HOTS could be stimulated by teachers asking higher order thinking questions, for examples, those to analyse by inspecting ideas, recognizing assumptions, identifying arguments, and spotting contradictions; to evaluate by comparing advantages and disadvantages, examining given criteria, and judging; to interpret by classifying, clarifying meaning, decoding significance and communicating in various media; to make inference by drawing conclusion, probing for evidence, and etc.; to explain by explaining methods and findings, justifying procedures, proposing and defending with reasons that stand critical examination; and questions asked with the purpose to create by designing, composing, adapting modifying, generating, rearranging, reconstructing and revising. According to Bloom Taxonomy, questions asking for analysis, evaluation, and creation are classified as higher order thinking questions (Bowker \& Fazioli, 2016; Christensen, 2017; Seker \& Komur, 2008).

The use of questions in the classroom is one of the ways that teachers convey popular teaching and is one of the easiest to implement (Albergaria, 2010a; Barbour, 2016; ). Questions posed by teachers can leverage student knowledge and reinforce teacher-taught lessons (Barbour, 2016). In the increasingly challenging world of education, science education in Malaysia has undergone a transformation of education that requires individual students to master HOTS. Thus, the two elements that can generate student achievement are through an inquiry approach and teacher questioning technique (Bjorklund \& Causey, 2017). The ability of a teacher to ask questions influences the questions asked (Albergaria, 2010b). Questions raised by teachers must test or evaluate what they have said during the $P \& P$ process (Christensen, 2017). Therefore, teacher questioning must be well-planned to meet the use of questions in an effective P\&P process. Teachers can use questions to challenge students' 
thinking (Bowker \& Fazioli, 2016). In addition, there are sources which find that, teachers and students' questions need to be enhanced to higher level questions, so that thinking processes become more meaningful and a fun learning environment (Darby \& Rashid, 2017; Fuad et al., 2017).

Therefore, in order to make the questionnaire more effective for the mastery of students' knowledge, it is important that teachers openly ask for particular attention in chemistry education in secondary schools in Malaysia.

\section{Statement of the Problem}

Questioning is the most commonly used classroom approach to enhance thinking. However, a thorough understanding of the nature and use of classroom questions is developed only recently. Why are questions so important? Questions play great roles in teaching and learning processes since student's achievements and their level of engagement rely significantly on the types of questions formulated and used by their teachers in a classroom. Learning is viewed by recent models of teaching and learning as a social activity, where students construct knowledge with the teacher and their peers. In this context, it is seen as a situated social practice, where students are developing identities as members of a particular community, and a socially negotiated and arbitrated process. In the same context, the teacher's role is to build on what their students already know and extend it by asking highlevel questions. It is through these scaffold interactions between the teacher and students which help learning and development of higher cognitive processing skills (Bergman \& Olson, 2011; Bjorklund \& Causey, 2017; Ng-Cheong \& Chin, 2009).

Asking philosophical questions is another approach to ask questions for developing HOTS. There are three types of questions: simple questions where simple thinking is required; questions which are not answered yet but can be answered through empirical researches; and complex questions where complex thinking is required. Complex questions which require rigorous thinking, known as philosophical questions, are the type of questions which stimulate HOTS. Definitely, the ability to ask the right type of questions is needed to engage students. Equally important, however, are the timing, sequence and clarity of questions planned to be asked. It is necessary to allow students ample waiting time, since answering often takes time for them to think, before the question is modified or other students are asked to respond. This requires certain things to be unlearnt, educational systems, institutions and educators to be relearnt and taken responsibility of, so that, competencies can be developed in addressing the 21st century's resolve and challenges with sustainability (Azeitero et al., 2015; Christensen, 2017).

Moreover, questions can be used to encourage students to talk about themselves and their experiences, besides directing the thinking process, stimulating and challenging students, provoking interest, forming the basis of research, influencing the social and emotional milieu of the teaching/learning environment, promoting discussion, and evaluating learning. It is important for teachers to have clear objectives for all science lessons and to coordinate questioning aimed towards particular directions. However, since students are often required to apply advanced forms of thinking by open ended questions, flexibility to ask a wide range of divergent questions would be advantageous in teaching. Teachers' questioning strategies have one of its dimensions in the form of motives. It seems to be increasingly to be aware about the aim and results of asking questions. Therefore, it is imperative for a teacher to plan questions before the beginning of the class and to use sufficient inquiry-based techniques in the classroom. These efforts will enhance and enrich 
their teaching, as well as developing students' thinking to make their learning more meaningful and enhance their excellence in form four Chemistry subject.

\section{Objectives of Study}

The objective of the study was to establish the relationship between High Order Thinking Skill (HOTS) and Teachers' Questioning Techniques in form four Chemistry subject.

\section{Research Methodology \\ Research Design}

A structured questionnaire was distributed to 218 respondents were selected as respondents for this study. They comprised 12 chemistry teachers, with 6 assistants' senior administrators and 200 students in Kuching district in Sarawak, West Malaysia. The sample size was determined using multistage random sampling technique. Five techniques used in chemistry teacher questioning were investigated. The study done before was not studied the research elements simultaneously. The study applied a correlation comparative research design. Questionnaire was used as data collection instruments. Questionnaires based on the survey methodology are convenient and useful for the measurement and evaluation of subjective concepts or personal feelings and are therefore broadly used throughout various research fields such as psychology, education and marketing. Data was analysed using frequencies, percentages, standard deviations; weighted means and Multiple Regression Analysis. The measurement model is used to test the relationship within constructs in the study. The quantitative data was analysed using Statistical Package for Social Sciences Version 21 software as a tool of analysis.

\section{Data Collection Instruments}

The data collection instruments used was a structured questionnaire. The study contributed significantly to theoretical and practical framework.

\section{Results and Discussion}

Table 1: Ranking and frequency of questioning techniques (Open and Closed-QTO)

\begin{tabular}{lllllllll}
\hline & $\mathrm{N}$ & $\mathrm{SD}=1$ & $\mathrm{D}=1$ & $\mathrm{~N}=3$ & $\mathrm{~A}=4$ & $\mathrm{SA}=5$ & WM & $\begin{array}{c}\text { Std. } \\
\text { Dev. }\end{array}$ \\
\hline QTO1 & 12 & 0 & 0 & 2 & 5 & 5 & 4.44 & 0.58 \\
QTO2 & 12 & 1 & 1 & 0 & 3 & 7 & 4.52 & 0.97 \\
QTO3 & 12 & 0 & 0 & 1 & 7 & 4 & 4.35 & 0.84 \\
QTO4 & 12 & 0 & 0 & 2 & 5 & 5 & 4.52 & 0.65 \\
QTO5 & 12 & 0 & 0 & 0 & 3 & 9 & 4.75 & 0.44 \\
QTO6 & 12 & 0 & 1 & 3 & 4 & 4 & 4.20 & 1.20 \\
QTO7 & 12 & 1 & 0 & 1 & 5 & 5 & 4.42 & 0.99 \\
\hline
\end{tabular}

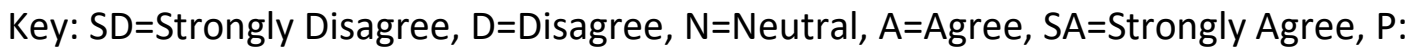
Percentage, WM: Weighted Mean, Std. Dev.: Standard Deviation.

(Std. Dev. $<0.5-$ Respondents responses crowded around the mean).

(Std. Dev.>0.5-Respondents responses dispersed on the responses). 
Table 2: Ranking and frequency of questioning techniques (Funnel-QTF))

\begin{tabular}{llccccccc}
\hline & $\mathrm{N}$ & $\mathrm{SD}=1$ & $\mathrm{D}=1$ & $\mathrm{~N}=3$ & $\mathrm{~A}=4$ & $\mathrm{SA}=5$ & WM & $\begin{array}{c}\text { Std. } \\
\text { Dev. }\end{array}$ \\
\hline QTF1 & 12 & 0 & 1 & 3 & 5 & 3 & 439 & 0.83 \\
QTF2 & 12 & 1 & 0 & 1 & 5 & 5 & 4.51 & 0.75 \\
QTF3 & 12 & 0 & 0 & 2 & 0 & 10 & 4.61 & 0.53 \\
QTF4 & 12 & 0 & 0 & 0 & 0 & 12 & 4.50 & 0.51 \\
\hline
\end{tabular}

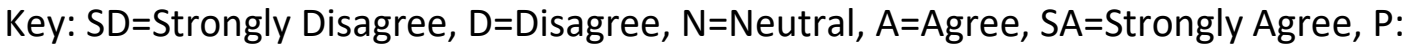

Percentage, WM: Weighted Mean, Std. Dev.: Standard Deviation.

(Std. Dev. $<0.5-$ Respondents responses crowded around the mean).

(Std. Dev.>0.5-Respondents responses dispersed on the responses).

Table 3: Ranking and frequency of questioning techniques (Probing-QTP)

\begin{tabular}{llccccccc}
\hline & $\mathrm{N}$ & $\mathrm{SD}=1$ & $\mathrm{D}=1$ & $\mathrm{~N}=3$ & $\mathrm{~A}=4$ & $\mathrm{SA}=5$ & WM & $\begin{array}{c}\text { Std. } \\
\text { Dev. }\end{array}$ \\
\hline QTP1 & 12 & 0 & 1 & 1 & 4 & 6 & 4.46 & 0.65 \\
QTP2 & 12 & 0 & 1 & 0 & 6 & 5 & 4.19 & 0.89 \\
QTP3 & 12 & 1 & 4 & 3 & 2 & 2 & 3.02 & 1.45 \\
QTP4 & 12 & 1 & 1 & 1 & 4 & 5 & 4.23 & 1.02 \\
\hline
\end{tabular}

Key: $\mathrm{SD}=$ Strongly Disagree, $\mathrm{D}=$ Disagree, $\mathrm{N}=$ Neutral, $\mathrm{A}=$ Agree, $\mathrm{SA}=$ Strongly Agree, $\mathrm{P}$ :

Percentage, WM: Weighted Mean, Std. Dev: Standard Deviation.

(Std. Dev. $<0.5-$ Respondents responses crowded around the mean).

(Std. Dev.>0.5-Respondents responses dispersed on the responses).

Table 4: Ranking and frequency of questioning techniques (Leading-QTL)

\begin{tabular}{lllllllll}
\hline & $\mathrm{N}$ & $\mathrm{SD}=1$ & $\mathrm{D}=1$ & $\mathrm{~N}=3$ & $\mathrm{~A}=4$ & $\mathrm{SA}=5$ & WM & $\begin{array}{c}\text { Std. } \\
\text { Dev. }\end{array}$ \\
\hline QTL1 & 12 & 0 & 2 & 0 & 8 & 2 & 3.34 & 1.24 \\
QTL2 & 12 & 1 & 1 & 1 & 7 & 2 & 3.02 & 1.33 \\
QTL3 & 12 & 0 & 2 & 1 & 7 & 2 & 3.29 & 1.34 \\
QTL4 & 12 & 1 & 1 & 0 & 6 & 4 & 3.12 & 1.04 \\
\hline
\end{tabular}

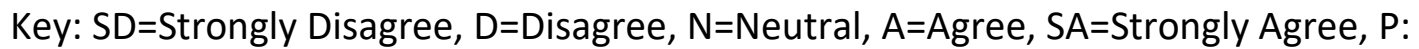

Percentage, WM: Weighted Mean, Std. Dev: Standard Deviation.

(Std. Dev. $<0.5-$ Respondents responses crowded around the mean).

(Std. Dev.>0.5-Respondents responses dispersed on the responses).

Table 5: Ranking and frequency of questioning techniques (Rhetorical-QTR))

\begin{tabular}{lllllllll}
\hline & $\mathrm{N}$ & $\mathrm{SD}=1$ & $\mathrm{D}=1$ & $\mathrm{~N}=3$ & $\mathrm{~A}=4$ & $\mathrm{SA}=5$ & WM & $\begin{array}{c}\text { Std. } \\
\text { Dev. }\end{array}$ \\
\hline QTR1 & 12 & 1 & 1 & 0 & 5 & 5 & 4.50 & 0.51 \\
QTR2 & 12 & 0 & 2 & 0 & 6 & 4 & 4.35 & 0.73 \\
QTR3 & 12 & 0 & 1 & 1 & 7 & 3 & 4.50 & 0.58 \\
QTR4 & 12 & 0 & 1 & 0 & 8 & 3 & 4.67 & 0.52 \\
QTR5 & 12 & 0 & 1 & 0 & 9 & 2 & 4.27 & 0.53 \\
\hline
\end{tabular}

Key: $\mathrm{SD}=$ Strongly Disagree, $\mathrm{D}=$ Disagree, $\mathrm{N}=$ Neutral, $\mathrm{A}=\mathrm{Agree}, \mathrm{SA}=$ Strongly Agree, $\mathrm{P}$ :

Percentage, WM: Weighted Mean, Std. Dev.: Standard Deviation.

(Std. Dev. $<0.5-$ Respondents responses crowded around the mean). 
(Std. Dev.>0.5-Respondents responses dispersed on the responses).

\section{Multiple Regression Analysis}

Model summary from table 1 shows a very strong positive multiple correlation between HOTS and Teachers' Questioning Techniques in Chemistry subject. In general, the model showed a statistically significant ( $p$-value $(0.000)>0.05$ ) association between the independent variable (HOTS) and the dependent variable (Teachers' Questioning Techniques in Chemistry subject). The coefficient of correlation $R$ of 0.704 indicated a strong positive multiple correlation between the independent variable and the dependent variable. Meanwhile, the coefficient of determination $R^{2}$ was 0.496 . The independent variables (HOTS), significantly explained $49,6 \%$ of variance in the Teachers' Questioning Techniques in Chemistry subject. The remaining portion of the percentage can be attributed to factors beyond the control of the study.

\begin{tabular}{|c|c|c|c|c|c|c|c|c|c|c|c|}
\hline \multirow{3}{*}{ Model } & \multicolumn{3}{|c|}{ Coefficients analysis } & \multirow{3}{*}{$\begin{array}{c}\mathbf{t} \\
\text { Valu } \\
\mathbf{e}\end{array}$} & \multirow{3}{*}{$\begin{array}{l}\text { Sig } \\
\cdot\end{array}$} & \multicolumn{2}{|c|}{ ANOVA } & \multicolumn{4}{|c|}{ Model Summary } \\
\hline & \multicolumn{2}{|c|}{$\begin{array}{l}\text { Unstandardi } \\
\text { sed } \\
\text { Coefficients }\end{array}$} & \multirow{2}{*}{$\begin{array}{c}\begin{array}{c}\text { Unstand } \\
\text { ardised } \\
\text { Coefficie } \\
\text { nts }\end{array} \\
\text { Beta } \\
\text { Value }\end{array}$} & & & & & & & & \\
\hline & B & $\begin{array}{l}\text { Std. } \\
\text { Erro } \\
r\end{array}$ & & & & $\begin{array}{l}\text { F- } \\
\text { Val } \\
\text { ue }\end{array}$ & $\begin{array}{l}\text { P- } \\
\text { Sig } \\
\text {. }\end{array}$ & $\mathbf{R}$ & $\begin{array}{l}\text { R } \\
\text { Squ } \\
\text { are }\end{array}$ & $\begin{array}{l}\text { Adjus } \\
\text { ted R } \\
\text { Squar } \\
\text { e }\end{array}$ & $\sum$ \\
\hline Constant & 7.876 & $\begin{array}{l}1.12 \\
2\end{array}$ & & 7.021 & $\begin{array}{l}0.0 \\
00\end{array}$ & & & & & & \\
\hline $\begin{array}{l}\text { OPEN_CLO } \\
\text { SED }\end{array}$ & -0.355 & $\begin{array}{l}0.19 \\
6\end{array}$ & -0.217 & $\begin{array}{l}- \\
1.813\end{array}$ & $\begin{array}{l}0.0 \\
77\end{array}$ & $\begin{array}{l}8.2 \\
58\end{array}$ & $\begin{array}{l}0.0 \\
00\end{array}$ & $\begin{array}{l}0.7 \\
04\end{array}$ & $\begin{array}{l}0.49 \\
6\end{array}$ & 0.436 & $\begin{array}{l}0.5 \\
89\end{array}$ \\
\hline FUNNEL & -0.351 & $\begin{array}{l}0.17 \\
2\end{array}$ & -0.257 & $\begin{array}{l}- \\
2.043\end{array}$ & $\begin{array}{l}0.0 \\
47\end{array}$ & & & & & & \\
\hline PROBING & -0.235 & $\begin{array}{l}0.11 \\
4 \\
\end{array}$ & -0.237 & $\begin{array}{l}- \\
2.069\end{array}$ & $\begin{array}{l}0.0 \\
45 \\
\end{array}$ & & & & & & \\
\hline LEADING & 0.110 & $\begin{array}{l}0.14 \\
0 \\
\end{array}$ & 0.090 & 0.789 & $\begin{array}{l}0.4 \\
35 \\
\end{array}$ & & & & & & \\
\hline $\begin{array}{l}\text { RHETORIC } \\
\text { AL }\end{array}$ & -0.285 & $\begin{array}{l}0.05 \\
7\end{array}$ & -0.587 & - & $\begin{array}{l}0.0 \\
00\end{array}$ & & & & & & \\
\hline
\end{tabular}

Key.

Predictors(Constant). Open \&closed, Funnel, Probing, Leading, Rhetorical.

a. Dependent Variable: Form four Performance in Chemistry subject. 
The $t$ and sig $(p)$ values indicate a statistical significance of each of the independent variables in predicting the dependent variable. A large absolute t value and a small $p$ value $(p<.05)$ points out that a predictor variable is significant in predicting the dependent variable. From the results of the analysis shown in Table 1, three out of five variables which had a significant factor in predicting Teachers' Questioning Techniques in Chemistry subject are as follows:

a) Teacher exprience in teaching Chemistry subject $(t=-4.983$ and $p=0.000)$, where $(p>0.05)$

b) Communication Skills ( $t=-2.043$ and $p=0.047)$, where $(p>0.05)$

c) Teaching Practice $(t=-2.069$ and $p=0.045)$, where $(p>0.05)$

The remaining two variables, found to have no significant factor in predicting Teachers' Questioning Techniques in Chemistry subject, are as follows:

d) Teachers Qualification ( $t=-0.789$ and $p=0.435)$, where $(p>0.05)$

e) Teachers Preparedness ( $t=-1.813$ and $p=0.077)$, where $(p>0.05)$ The following final regression models was developed.

Playing a significant role in developing critical thinking skills at all tiers of education, questions are one of the primary tools which teachers and students utilise to realise pedagogical objectives. In this context, questioning strategies which motivate students to engage themselves in analysis, problem-solving, and inquiry activities should be used. Inconsistent, imprecise and ambiguous questions can only confuse students, rendering them unable to be involved and to engage in discussions. Similarly, questions which are conceptualised and formulated at low levels of Bloom's taxonomy tend to restrict the level of challenge which students will experience during the learning process. The implicit message given to the students through such low-level questions is that, this level of learning is more important while it is unlikely to encourage them to engage in higher-level learning. In addition, questions can be utilised to activate meta-cognitive processes which produce more efficient learning. Simultaneously, questions can drive thought beneath the surface of thinking, forcing an individual to deal with complexities. In education, questions have various functions. Students are led to define tasks by questions of purpose, while they are enabled to look at their sources of information by questions of information. Students are assisted to assess the way they organise or give meaning to information by interpretation questions and they are forced to assess what they take for granted by questions of assumption. Last but not least, students are assisted to assess their perspective and consider other relevant viewpoints by questions of point of view.

Critical thinking revolves around assessing presented information to challenge or test the concepts or claims within the information. Critical thinkers may compare new theories with similar theories which they already accept to be true. Questions must be well phrased to avoid ambiguity of responses, to prevent required emphasis from being placed on no pertinent information, to reduce the possibility of a correct response by merely guessing and to target specific cognitive processing skills. As described in the teacher education literature, questioning is the intentional use of questions to engage learners in applying knowledge and in developing critical thinking skills.

Moreover, all fields only remain relevant to the extent that fresh questions are generated and attended to seriously as the driving force in thinking. To think through and rethink, questions which stimulate thought must be asked. Questions define tasks, delineate issues and express problems, and they often signal a full stop in thought. Thought remains 
alive only when an answer generates a further question, the reason thinking and learning only take place when there are questions to be asked. There are marked differences in teachers' uses of questioning. In many cases, attention is focused on the subject, and therefore, efforts are made to follow carefully a strict teaching plan, by asking questions structured towards certain intended responses. A quite different case is where emphasis is placed on eliciting students' ideas through questioning. In the latter situation, teachers might give encouragement to a much wider range of student responses.

\section{Conclusion}

For centuries, questioning has been widely utilized as an instrument for critical assessments. In fact, it is one of the most important elements in teaching, and, when used appropriately, it can be highly effective. It is also used by teachers to enhance student motivation and to gain class control, besides motivating the reluctant students to participate in classroom activities The teaching of chemistry, as in other science subjects, involves laboratory and project work, besides the classroom activities. In all these forms of learning, questioning methods make up form the framework for students' learning experience. In using questioning, considered to be a powerful and universal teaching strategy, teachers are expected to put up an incredible number of questions. Questions are used to check recall of an increase retention of information, to guide the development of concepts or skills, to interpret information, evaluate learning, to promote thinking, and to review.

Asking questions is, in no doubt, important, and its effectiveness relies on how purposefully teachers select their questions to achieve certain set goals. Unless the purpose of a question is pre-determined, disorder, chaos and eventually the inability to learn can be expected in the outcome. The extent to which pre-determined goals are attained is what determines if a question is appropriate or otherwise. Questions which are developed on varying mental operations and recognise the wide possibilities of thought are said to be good questions. Classroom questions can help students to develop more diversified and effective thinking. This should enable them to become independent learners and prove valuable throughout their lives. A period of time, known as, wait time, is an important element of teacher questioning. While the student to whom the question was addressed answers the question, the teacher and his or her peers wait silently. The key drivers of sustainable education or education for sustainable development would be able to answer three fundamental questions. Overall, as educators, having a clear intent for questioning only is inadequate, as learning to ask the right questions is equally important. It is paramount for educators to question on learning outcome (content), besides students' thinking and learning processes along the course of guiding their students during the learning process.

Experiencing questions at repetitively low levels limits student's opportunities to further develop their ideas and to be supported to reach higher cognitive levels. One dimension of teachers' questioning strategies involves motives. The awareness of the aim and results of asking questions seems to be important. The awareness of the aim and results of asking questions seems to be important. A period of time, known as, wait time, is an important element of teacher questioning. While the student to whom the question was addressed answers the question, the teacher and his or her peers wait silently. Students must be given the opportunity to respond to high-level questions to stimulate their thinking. Giving them more challenging, high-level questions will also encourage them to express their opinions, to make their decisions. Besides, they will be motivated to find solutions to any given problem, or to generate new ideas related to the content of education. Furthermore, 
they will be able to reach a consensus on meanings of concepts; analyse and formulate a clear problem; build on the ideas given by their peers and synthesize ideas which ultimately result in creative innovations. Questioning techniques used by teachers which correlate with enhanced achievement, include a balance of convergent and divergent questions, listening to student responses, probing questions, providing respectful feedback, redirecting student responses to other students and allowing for sufficient waiting time after putting up a question. Convergent questions aimed to get low level cognitive information from students, while divergent or open-ended questions are intended to stimulate a discussion and foster an interactive and democratic classroom environment for case study teaching. The importance of the use of questions and how they form the basis of knowledge, decision making, and actions is integral to the promotion of critical thinking.

\section{References}

Albergaria-Almeida, P. (2010a). Classroom questioning: teachers' perceptions and practices. Procedia-Social and Behavioral Sciences, 2(2), 305-309.

Albergaria-Almeida, P. (2010b). Questioning patterns and teaching strategies in secondary education. Procedia-Social and Behavioral Sciences, 2(2), 751-756.

Azeiteiro, U. M., Bacelar-Nicolau, P., Caetano, F. J., \& Caeiro, S. (2015). Education for sustainable development through e-learning in higher education: experiences from Portugal. Journal of Cleaner Production, 106, 308-319.

Barth, M., \& Michelsen, G. (2013). Learning for change: an educational contribution to sustainability science. Sustainability science, 8(1), 103-119.

Barbour, S. C. (2016). A study of teaching methods to enhance creativity and critical thinking in graphic design. (Unpublished Doctoral dissertation). Iowa State University, USA

Bergman, D. J., \& Olson, J. (2011). Got inquiry? Science \& Student, 48(7), 44-48.

Bixler, G. M., Brown, A., Way, D., Ledford, C., \& Mahan, J. D. (2015). Collaborative concept mapping and critical thinking in fourth-year medical students. Clinical Pediatrics, 54(9), 833-839.

Bjorklund, D. F., \& Causey, K. B. (2017). Student's thinking: Cognitive development and individual differences. SAGE Publications

Bowker, M. H., \& Fazioli, K. P. (2016). Rethinking critical thinking: A relational and contextual approach. Pedagogy and the Human Sciences, 6(1), 1-26

Christensen, C. L. (2017). What Is The Impact Of Effective Questioning And Critical, Relevant Conversations On Sixth Grade Science Students' Agentic Engagement?.Master of Arts in Education: Natural Science and Environmental Education. Hamline University, Saint Paul, Minnesota.

Darby, N. M., \& Rashid, A. M. (2017). Critical thinking disposition: The effects of infusion approach in engineering drawing. Journal of Education and Learning, 6(3), 305.

Facione, P. A. (2006). Critical thinking: what it is and why it counts, Insight Assessment, California, , 1-22, United States: California Academic Press.

Fuad, N. M., Zubaidah, S., Mahanal, S., \& Suarsini, E. (2017). Improving junior high schools' critical thinking skills based on test three different models of learning. International Journal of Instruction, 10(1), 101-116.

Harlen, W. (2014). The Teaching of Science in Primary Schools, 6th Edition. New York, Routledge.

Ng-Cheong, J. S., \& Chin, C. (2009). Questioning as a learning strategy in primary science.. International Science Education Conference, Singapore, 24-26 November 2009. 
Laws, J. M. (2016). The Laws Guide to Nature Drawing and Journaling. Berkeley, CA: Heyday. Lowery, L. (2010). Investigative Questions are the Sparks that Ignite Inquiry. Science and Student, Arlington, VA, National Science Teachers Association.

Barnum, M. G. (2008). Questioning skills demonstrated by approved clinical instructors during clinical field experiences. Journal of Athletic Training, 43(3), 284-292.

Michaels, S., \& O'Connor, C. (2012). Talk science primer. Cambridge, MA: TERC.

Parker, M., \& Hurry, J. (2007). Teachers' use of questioning and modelling comprehension skills in primary classrooms. Educational Review, 59(3), 299-314. doi: 10.1080/0013191070 1427298.

Sanders, S. (2016). Critical and creative thinkers in mathematics classrooms. Journal of Student Engagement: Education Matters, 6(1), 19-27.

Samson, G. K., Strykowski, B., Weinstein, T., \& Walberg, H. J. (1987). The Effects of Teacher Questioning Levels on Student Achievement. The Journal of Educational Research, 80(5), 290-295. doi:10.1080/00220671.1987.10885769.

Seker, H., \& Komur, S. (2008). The relationship between critical thinking skills and in-class questioning behaviours of English language teaching students. European Journal of Teacher Education, 31(4), 389-402. doi:10.1080/02619760802420784

Thomas and Depasquale. (2016). Connecting curriculum, capabilities and careers. Int. J. Sustain. High. Educ. 17, 738-755.

Tofade, T., Elsner, J., \& Haines, S. T. (2013). Best Practice Strategies for Effective Use of

Questions as a Teaching Tool. American Journal of Pharmaceutical Education, 77(7), 155. doi:10.5688/ajpe777155

Van den Branden, K. (2015). Task-based language education. From theory to practice. . . and back again. In Bygate, M. (Ed.), Domains and directions in the development of TBLT (pp. 303-320). Amsterdam, The Netherlands: John Benjamins.

Wilen, W. W., \& Clegg, A. A. (1986). Effective Questions and Questioning: A Research Review. Theory \& Research in Social Education, 14(2), 153-161. doi:10.1080/00933104.1986.10505518

Yusoff, W. M. W., \& Seman, S. C. (2018). Teachers' Knowledge of Higher Order Thinking and Questioning Skills: A Case Study at a Primary School in Terengganu, Malaysia. International Journal of Academic Research in Progressive Education and Development, $7(2), 45-63$. 